\title{
NUMERICAL ALGORITHM FOR OPTIMAL CONTROL DEVELOPMENT FOR ANNEALING STAGE OF POLYMERASE CHAIN REACTION
}

\author{
Andrii Sverstiuk \\ Ternopil State Medical University, Ternopil, Ukraine
}

\begin{abstract}
Summary. In the work the general methodology of control is used for obtaining the solution of the problem of optimal annealing stage in a polymerase chain reaction in order to effectively conduct the study and the possibility of providing a multi-stage cyclic regime of temperature change. The annealing stage should occur at certain temperatures and over time, because otherwise the necessary transformations of DNA molecules may not occur. The developed model of annealing stage of the polymerase chain reaction, which takes into account the ratio of the number of single-stranded DNA, primer, single-stranded DNA bound to the primer, direct and reverse reaction rate for annealing, was used. In the model under study, the Arrhenius equation is used, which takes into account the dependence of the reaction rate on absolute temperature. The principle of Pontryagin's maximum is applied to the problem of optimal control of annealing stage and the necessary optimality condition is formulated. The direct method of numerical solving of the problem of optimal annealing control, which is implemented in the package of Java classes, is developed. In the form of graphs are presented the results of numerical simulation of the problem of optimal control of the annealing stage polymerase chain reaction. The results of numerical modeling of the optimal control of the annealing stage of polymerase chain reaction for changing the number of single-stranded DNA, the number of primers, changes in the number of single-stranded DNA that are connected to the primer and the optimal temperature value of the investigated stage are constructed. The obtained results of numerical simulation of the problem of optimal control of the annealing stage of polymerase chain reaction will help to minimize the necessary time for the implementation of this stage. The scheme of temperature setting thus constructed minimizes the required time of implementation of the annealing stage, which in the general case will ensure the achievement of the minimum time for polymerase chain reaction.
\end{abstract} principle.

Key words: polymerase chain reaction; annealing stage; optimal control; the Pontryagin maximum

Statement of the problem. Polymerase chain reaction (PCR) is the method of molecular biology based on the significant increase of small concentrations of deoxyribonucleic acid (DNA) fragments in biological material by means of amplification. PCR is widely used in biological and medical practice for cloning genes, mutations diagnosis, new genes allocation, sequencing, and genetically modified organisms creation and determination $[1,2]$.

Analisys of the available investigation results. PCR reaction is based on multiple replication (selective amplification) of the investigated DNA by DNA polymerase enzyme. The generated DNA copies are identified by electrophoresis.

While carrying out PCR, 20-35 cycles [1] are performed, each of them consists of three stages.

The double-stranded DNA matrix is heated to $94-96^{\circ} \mathrm{C}$ (or up to $98^{\circ} \mathrm{C}$, if specific thermostable polymerase is used) for $0.5-10 \mathrm{~min}$, so in order to divide DNA chains. This stage is called denaturation - decomposition of hydrogen bonds between two chains. Sometimes before the first cycle, the reaction mixture is preheated during 2-5 minutes for the complete denaturation of the matrix and primers. 
When chains split, the temperature is reduced so that the primers can bound the singlechain matrix. This stage is called annealing. The annealing temperature depends on the primers and is usually selected at $4-5^{\circ} \mathrm{C}$ than their melting point. The stage time is $0.5-2 \mathrm{~min}$.

DNA polymerase replicates the matrix chain using the primer as inoculation. This is the so-called elongation stage. The elongation temperature depends on the polymerase. The most commonly used Taq i Pfu polymerase are the most active at $72^{\circ} \mathrm{C}$. The elongation time depends on both the type of DNA polymerase and the length of the fragment which is amplified. The average elongation rate -1000 base couples for $1 \mathrm{~min}$. At the end of all cycles, the additional stage of final elongation is often carried out to complete all single-strand fragments. This stage lasts 10-15 minutes.

In order to carry out efficient PCR, it is necessary to provide multi-stage cyclic mode of temperature change. Figure 1 shows the example of the temperature regimes setting for respective PCR stages in the software of Rotor-GeneTM 6000 thermal cycler.

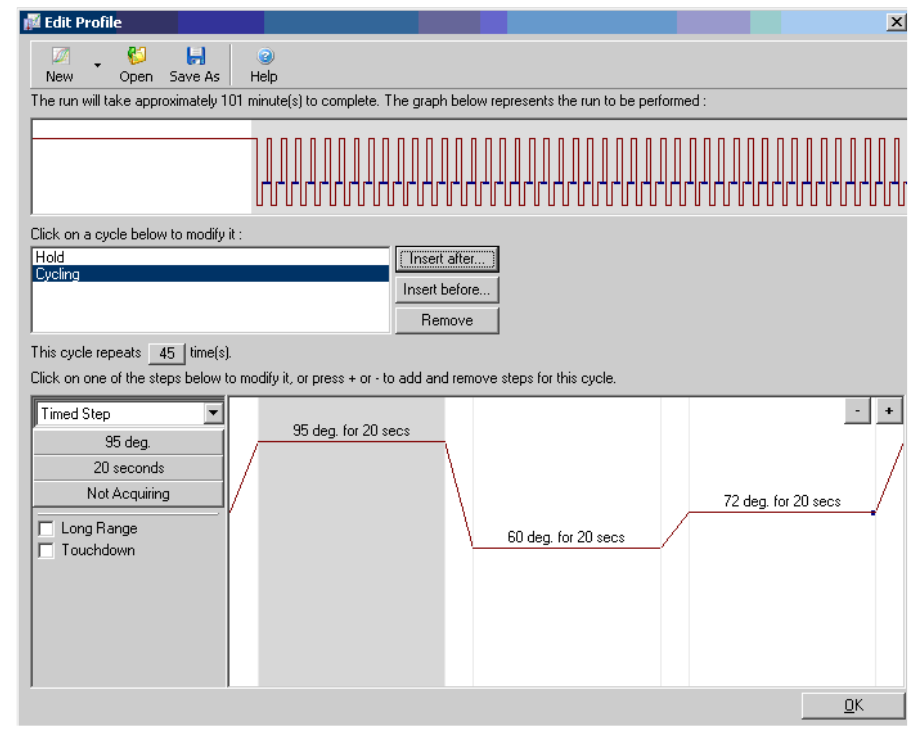

Figure 1. The PCR stage temperature regimes setting in Rotor-GeneTM 6000 thermal cycler software

Each cycle stage (denaturation, annealing, elongation) should occur at certain temperatures during the given time. Otherwise, the necessary DNA molecules transformations may not occur.

Many papers [2-7] represent the models of different PCR stages, but for more effective use of PCR methods, it is efficient to carry out the investigations of data management models.

The objective of the work is to develop the numerical algorithm for optimal control of the stage polymerase chain reaction annealing stage.

Statement of the problem. While developing the numerical algorithm, it is necessary to use the mathematical model of annealing stage of polymerase chain reaction taking into account the process of primer addition to the single-stranded DNA, direct and inverse reaction rate constants. It is necessary to construct the compartment model of annealing stage.

For the annealing stage, the condition for obtaining as many single-stranded DNA as possible bound with the primer must be taken into account, while using the smallest primer amount. It is efficient to develop the direct method of numerical solving of the problem of optimal investigated stage control. It is necessary to obtain the results of numerical simulation of the problem of optimal control of annealing stage polymerase chain reaction in the form of graphs. The dependences of the single-stranded DNA amount, primer, single-stranded DNA 
buond to the primer, as well as the optimal temperature value of the annealing phase of polymerchain reaction on time should be presented.

Thus, the problem of mathematical modeling and corresponding calculations is to estimate the minimum time required for annealing stage implementation, which in general will ensure the attaining the minimum time for PCR.

The results of the investigation. Mathematical modeling of PCR annealing stage.

At the annealing stage, the mixture temperature is reduced to $55^{\circ} \mathrm{C}$, the primers are bounded to the single-stranded DNA target. The primers are chosen in such a way as to restrict the desired fragment and are complementary to opposite DNA strands

The simplified chemical equation describing the process of $p$ primer bounding to the single-stranded DNA $s$ can be represented as follows:

$$
s+p \stackrel{k_{1}, k_{-1}}{\leftrightarrow} s^{\prime}
$$

As the result of annealing stage, one-stranded DNA bound to primer $s^{\prime}$ is formed. In equation (1) $k_{1}$ and $k_{-1}$ are direct and reciprocal reaction rate constants for annealing.

Using equation (1) let us construct the annealing compartment model in the following form (Fig. 2).

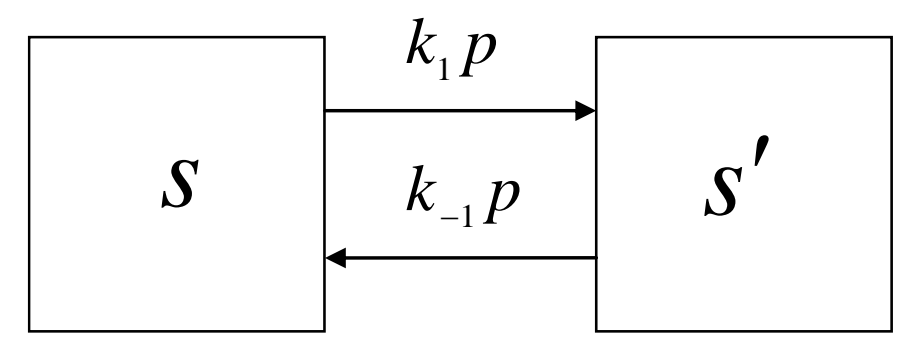

Figure 2. Compartment model of PCR annealing stage

It is evident from Fig. 2 that the direct constant of the reaction rate for annealing $k_{1}$ benefits to the formation of single-stranded DNA bound to the primer. The constant $k_{-1}$ simulates the inverse reaction of the investigated stage, at which the primers fall apart the previously formed single-stranded DNA bounded with primer $s^{\prime}$.

The temperature mode of PCR annealing stage of is chosen in such a way that $k_{1}>k_{-1}$.

Theoretical foundations of PCR optimal control. In the problems of PCR optimal control due to the temperature, a variety of controls is considered:

$$
U=\left\{u(t): a \leq u(t) \leq b, \quad t_{1} \leq t \leq t_{2}, \quad u(t)-\text { measured }\right\} .
$$

Here $a, b, t_{1}, t_{2}>0$.

It is assumed that the state of the system $x(t) \in R^{n}$ under the given control $u \in U$ is determined by the system of ordinary differential equations: 


$$
\begin{aligned}
& \frac{d x(t)}{d t}=f(t, x, u), \\
& x\left(t_{0}\right)=x_{0}
\end{aligned}
$$

where $f: R \times R^{n} \times R \rightarrow R^{n}$ is continuous and has continuous first partial derivatives relatively to $x$ and $u$. Since it is assumed that $u(t)$ is measurable and limited, then the righthand part of the system (2) is continuous relatively $x$ and is measurable only relatively $t$ to the fixed $x$. Thus, the solutions (1) are absolutely continuous functions satisfying (2) almost everywhere. Under such conditions of solution (2) existence $x(t, u)$ is proved in papers $[8,9]$.

The problem of optimal control includes the quality criterion $J[u]$ as:

$$
J[u]=\int_{t_{1}}^{t_{2}} L(t, x, u) d t+\phi\left(x\left(t_{2}\right)\right),
$$

where $L$ is the given real-valued function and $\phi$ is continuously differentiable real-valued function. The objective is to find $u^{*} \in U$ control such as

$$
J\left[u^{*}\right]=\inf _{T \in U} J[u] .
$$

When the model is described and the quality criterion is determined in the theory of optimal control, a set of problems [10] is formulated:

- proof of the optimal control existence;

- description of the optimal control construction;

- proof of the optimal control uniqueness;

- numerical calculation of optimal control;

- investigation of the optimal control dependence on model parameters.

Sufficient conditions of the optimal control existence for the problem (2)-(3) without terminal component in the quality criterion are given in papers $[10,11]$.

Theorem 1. The problem of optimal control (2) - (3) on the fixed interval $\left[t_{1}, t_{2}\right]$ is considered. Let us assume that:

1) there is such constant $M>0$ that $\|x(t, u)\| \leq M$ for all $u \in U$ and $t_{1} \leq t \leq t_{2}$;

2) $L$ is semicontinuous at the bottom;

3) set $D^{+}=\left\{\left(y^{0}, y\right): \exists v \in U, y=f(t, x, v), y^{0} \geq L(t, x, v)\right\}$ is convex for $(t, x) \in\left[t_{1}, t_{2}\right] \times\{|x| \leq M\}$.

Then there is optimal control $u^{*} \in U$.

The description of the optimal control construction for problem (2)-(3) gives the principle of Pontryagin's maximum with the terminal component $[12,13]$

Theorem 2. Suppose $u^{*} \in U$ is the optimal control in problem (2)-(3). Then there is the conjugate function $\lambda: R \rightarrow R^{n}$ such that $x\left(t, u^{*}\right), u^{*}, \lambda$ satisfy the system: 


$$
\begin{aligned}
& \frac{d x(t)}{d t}=f\left(t, x, u^{*}\right), \\
& x\left(t_{1}\right)=x_{1}
\end{aligned}
$$

and the conjugate system:

$$
\begin{aligned}
& \frac{d \lambda(t)}{d t}=-\frac{\partial H}{\partial x}=-L_{x}\left(t, x, u^{*}\right)-\lambda^{T} f_{x}\left(t, x, u^{*}\right), \\
& \lambda\left(t_{2}\right)=\phi^{\prime}\left(x\left(t_{2}\right)\right), \text { condition of transversality, }
\end{aligned}
$$

where Hamilton-Pontryagin function is given as follows:

$$
H(t, x, u)=L(t, x, u)+\lambda^{T} f(t, x, u) .
$$

The problem of optimal control of PCR annealing stage. considered:

The problem of optimal control of PCR annealing stage proposed in paper [7] is

$$
\left\{\begin{array}{l}
\frac{d s}{d t}=-k_{1} s p+k_{-1} s^{\prime} \\
\frac{d p}{d t}=-k_{1} s p+k_{-1} s^{\prime} \\
\frac{d s^{\prime}}{d t}=k_{1} s p+k_{-1} s^{\prime}
\end{array}\right.
$$

In the system (6): $s$ is the single-stranded DNA, $p$ is the primer, $s^{\prime}$ is the singlestranded DNA bound to the primer, $k_{1}, k_{-1}$ are direct and reverse reaction rates for annealing.

While performing PCR annealing phase, the temperature is the controlling effect $[4,5]$. The dependence of the reaction rate $k$ on the absolute temperature $T$ is described by Arrhenius equation [14]:

$$
k=A e^{-E_{a} / R T},
$$

where $A$ characterizes the molecules collision frequency, $R$ is the universal gas constant, $E_{a}$ is the activation energy.

By reference to Arrhenius equation (8), the system of differential equations for the annealing stage (7) can be specified as follows:

$$
\left\{\begin{array}{l}
\frac{d s}{d t}=-k_{1} e^{-\frac{r}{T}} s p+k_{-1} e^{-\frac{r}{T}} s^{\prime} \\
\frac{d p}{d t}=-k_{1} e^{-\frac{r}{T}} s p+k_{-1} e^{-\frac{r}{T}} s^{\prime} \\
\frac{d s^{\prime}}{d t}=k_{1} e^{-\frac{r}{T}} s p-k_{-1} e^{-\frac{r}{T}} s^{\prime}
\end{array}\right.
$$


with the corresponding initial conditions:

$$
s\left(t_{1}\right)=s_{0}, p\left(t_{1}\right)=p_{0}, s^{\prime}\left(t_{1}\right)=s_{0} .
$$

In the system of differential equations (9) $r=\frac{E_{a}}{R}$ is the constant.

Let us consider $T=T(t)$ as control function.

Let us assume that $T(t) \in\left[T_{e}^{\min }, T_{e}^{\max }\right]$.

The objective of the annealing stage is to obtain as many single-stranded DNA as possible which are bound to the prime $s^{\prime}$ with the smallest amount of primer $p$ consumed, i.e.:

$$
J\left(s, p, s^{\prime}\right)=\int_{t_{1}}^{t_{2}}\left(s^{\prime 2}(t)-W p^{2}(t)\right) d t \rightarrow \inf _{T \in U}
$$

Here $W>0$ is the weight coefficient, $U$ is the set of piecewise continuous functions $T(t) \in\left[T_{e}^{\min }, T_{e}^{\max }\right]$.

Biologically significant area is:

$$
\Omega_{1}=\left(s, p, s^{\prime}\right) \in R_{+}^{3}
$$

imposing phase restrictions:

$$
s \geq 0, p \geq 0, s^{\prime} \geq 0
$$

So, the objective is to determine the optimal control $T^{*} \in U$ that satisfies:

$$
J\left[T^{*}\right]=\inf _{T \in U} J[T] .
$$

On the basis of Theorem 1, it is evident that optimal control in problem (7)-(14) exists, since the subintegral expression in the quality criterion is the convex function, and the system trajectory belongs to space $L^{\infty}$.

Let us apply Theorem 2 to obtain the necessary optimality conditions. HamiltonPontryagin function is as follows:

$$
\begin{aligned}
& H=s^{\prime 2}-W p^{2}+\lambda_{1}\left(-k_{1} e^{-\frac{r}{T}} s p+k_{-1} e^{-\frac{r}{T}} s^{\prime}\right)+ \\
& +\lambda_{2}\left(-k_{1} e^{-\frac{r}{T}} s p+k_{-1} e^{-\frac{r}{T}} s^{\prime}\right)+\lambda_{3}\left(k_{1} e^{-\frac{r}{T}} s p-k_{-1} e^{-\frac{r}{T}} s^{\prime}\right)
\end{aligned}
$$

Hence, we get the conjugate system from Theorem 2:

$$
\left\{\begin{array}{l}
\frac{d \lambda_{1}}{d t}=-\frac{\partial H}{\partial s}=k_{1} e^{-\frac{r}{T}} p\left(\lambda_{1}+\lambda_{2}-\lambda_{3}\right) \\
\frac{d \lambda_{2}}{d t}=-\frac{\partial H}{\partial p}=2 W p+k_{1} e^{-\frac{r}{T}} s\left(\lambda_{1}+\lambda_{2}-\lambda_{3}\right) \\
\frac{d \lambda_{3}}{d t}=-\frac{\partial H}{\partial s^{\prime}}=k_{-1} e^{-\frac{r}{T}}\left(\lambda_{3}-\lambda_{1}-\lambda_{2}\right)-2 s^{\prime}
\end{array}\right.
$$


Let us denote:

$$
\begin{aligned}
& \Phi(t)=\lambda_{1}\left(-k_{1} e^{-\frac{r}{T}} s p+k_{-1} e^{-\frac{r}{T}} s^{\prime}\right)+ \\
& +\lambda_{2}\left(-k_{1} e^{-\frac{r}{T}} s p+k_{-1} e^{-\frac{r}{T}} s^{\prime}\right)+\lambda_{3}\left(k_{1} e^{-\frac{r}{T}} s p-k_{-1} e^{-\frac{r}{T}} s^{\prime}\right.
\end{aligned}
$$

Taking into account (17) Hamilton-Pontryagin function (15) is written as:

$$
H=s^{\prime 2}-W p^{2}+e^{-\frac{r}{T}}[\Phi(t)]
$$

Here we see that the maximum values $H$ will be reached at $T=T^{*}(t)$, where:

$$
T^{*}(t)=\left\{\begin{array}{l}
T_{e}^{\min }, \text { for } \Phi(t)>0 \\
T_{e}^{\max }, \text { for } \Phi(t)<0 \\
\forall\left[T_{e}^{\min }, T_{e}^{\max }\right], \text { for } \Phi(t)=0
\end{array}\right.
$$

Thus, the optimal trajectory $\left(s^{*}, p^{*}, s^{\prime *}\right)$ for control $T^{*}$ can be constructed as the result of the boundary problem solution:

$$
\left\{\begin{array}{l}
\frac{d s}{d t}=-k_{1} e^{-\frac{r}{T^{*}}} s p+k_{-1} e^{-\frac{r}{T^{*}}} s^{\prime} \\
\frac{d p}{d t}=-k_{1} e^{-\frac{r}{T^{*}}} s p+k_{-1} e^{-\frac{r}{T^{*}}} s^{\prime} \\
\frac{d s^{\prime}}{d t}=k_{1} e^{-\frac{r}{T^{*}}} s p-k_{-1} e^{-\frac{r}{T^{*}}} s^{\prime} \\
\frac{d \lambda_{1}}{d t}=-\frac{\partial H}{\partial s}=k_{1} e^{-\frac{r}{T^{*}}} p\left(\lambda_{1}+\lambda_{2}-\lambda_{3}\right) \\
\frac{d \lambda_{2}}{d t}=-\frac{\partial H}{\partial p}=2 W p+k_{1} e^{-\frac{r}{T^{*}}} s\left(\lambda_{1}+\lambda_{2}-\lambda_{3}\right) \\
\frac{d \lambda_{3}}{d t}=-\frac{\partial H}{\partial s^{\prime}}=k_{-1} e^{-\frac{r}{T^{*}}}\left(\lambda_{3}-\lambda_{1}-\lambda_{2}\right)-2 s^{\prime}
\end{array}\right.
$$

With boundary conditions:

$$
s\left(t_{1}\right)=s_{0}, p\left(t_{1}\right)=p_{0}, s^{\prime}\left(t_{1}\right)=s_{0}^{\prime} ; \lambda_{1}\left(t_{2}\right)=0, \lambda_{2}\left(t_{2}\right)=0, \lambda_{3}\left(t_{2}\right)=0 \text {. }
$$

Theorem 3. For sufficiently small value $t_{2}$, the system solution (20) is unique.

Proof. Let us assume, on the contrary, that there are two solutions (20), i. e.:

$$
\begin{gathered}
X^{*}=\left(s^{*}, p^{*}, s^{\prime *}, \lambda_{1}^{*}, \lambda_{2}^{*}, \lambda_{3}^{*}\right) \mathrm{i} \\
X^{* *}=\left(s^{* * *}, p^{* *}, s^{\prime * *}, \lambda_{1}^{* *}, \lambda_{2}^{* *}, \lambda_{3}^{* *}\right) .
\end{gathered}
$$


The right-hand parts of system (20) are Lipschitz functions of arguments $s, q, s^{\prime}, \lambda_{1}, \lambda_{2}, \lambda_{3}$. Hence, there is such constant $C>0$ that:

$$
\left\|X^{*}(t)-X^{* *}(t)\right\| \leq \int_{t_{1}}^{t_{2}} C\left(\left\|X^{*}(s)-X^{* *}(s)\right\|\right) d s
$$

Applying the mean value theorem to (21), we have that there exists such time moment $\xi: t_{1} \leq \xi \leq t_{2}$ that:

$$
\left\|X^{*}(t)-X^{* *}(t)\right\| \leq t_{2} C\left(\left\|X^{*}(\xi)-X^{* *}(\xi)\right\|\right)
$$

for all $t \in\left[t_{1}, t_{2}\right]$. If we chose $t_{2}$ in such a way, that $t_{2}<\frac{1}{C}$, then we get the contradiction.

Numerical calculation of optimal control. Methods of numerical solution of optimal control problems can be classified as direct and indirect $[15,16]$. These methods differ in approaches for finding the solution of the optimal control problem. Indirect methods tend to solve the boundary problem of the required optimality conditions. On the contrary, direct methods do not need the direct construction of the required conditions. Direct methods do not build the conjugate system, control system and transversability conditions. Investigating optimal control, both approaches are used. The main disadvantage of using indirect methods is that even knowing exactly the acceptable state and control, there is no guarantee that the calculated solution will improve the known one. Moreover, the indirect method requires initial approximation values for conjugate variables, and the numerical solution of the conjugate system in practice is ill-posed problem [17].

For this reason, we have used the direct method proposed in paper [18], which makes it possible to find numerical solutions of the problems that are even more general from (7) the statement.

Statement of the optimal control problem for the direct method. The control system for phase coordinates $x(t) \in R^{n}$, control vector $T(t) \in R^{m}$ and unknown parameters $p \in R^{n_{p}}$ is considered.

$$
\begin{aligned}
& \frac{d x(t)}{d t}=f(t, x, T, p), \\
& x\left(t_{0}\right)=x_{0}
\end{aligned}
$$

Restrictions on the state of the system, control and parameters are imposed as the following equations:

$$
c(t, x, T, p)=0, \quad t \in\left[t_{1}, t_{2}\right]
$$

where $c(t, x, T, p) \in R^{n_{c}}$, as the following inequalities:

$$
d(t, x, T, p) \leq 0, \quad t \in\left[t_{1}, t_{2}\right]
$$

where $d(t, x, T, p) \in R^{n_{d}}$, 
restrictions on the system state at the final time moment and parameters are as follows:

$$
\psi\left(x\left(t_{2}\right) p\right)=0
$$

where $\psi\left(x\left(t_{2}\right), p\right) \in R^{n_{\psi}}$,

as following inequalities:

$$
\gamma\left(x\left(t_{2}\right) p\right) \leq 0
$$

where $\gamma\left(x\left(t_{2}\right), p\right) \in R^{n_{\gamma}}$.

The task is to find control $T(t) \in R^{m}$ and parameters $p \in R^{n_{p}}$ which minimize the quality criterion:

$$
J[T, p]=\int_{t_{0}}^{t_{2}} L(t, x, T, p) d t+\phi\left(x\left(t_{2}\right), p\right),
$$

that is:

$$
J\left[T^{*}, p^{*}\right]=\inf _{T, p \in(16)-(19)} J[T, p] .
$$

It should be noted that stating problem (23)-(28) we assumed that $t_{2}$ is fixed, this problem can be adapted to the optimal velocity problem. This can be done by normalizing the time variable $t$ and putting the unknown final time as the parameter.

Numerical method. The method lies in the fact that the infinite-dimensional problem of type (7) is reduced to the finite-dimensional optimization problem.

This is achieved by discretization the time interval $t \in\left[t_{1}, t_{2}\right]$ using $N$ nodes $t_{i}$ such as $t_{1}=t_{1}<t_{2}<\ldots<t_{N-1}=t_{f}$.

At each time moment $t_{i}$ the control is the unknown scalar vector $\bar{T}_{i} \in R^{m}$. At each open interval $t \in\left(t_{i}, t_{i+1}\right), i=\overline{0, N-2}$ control approaches by the following linear approximation:

$$
T(t)=\bar{T}_{i}+\frac{t-t_{i}}{t_{i+1}-t_{i}}\left(\bar{T}_{i+1}-\bar{T}_{i}\right) .
$$

A set of control vectors in nodes $t_{i}$ models the common vector:

$$
\tilde{T}=\left[\tilde{T}_{0}^{T}, \ldots, \tilde{T}_{N-1}^{T}\right]^{T}
$$

For the given initial approximation $\tilde{u}$, we can integrate (27) on $t \in\left[t_{1}, t_{2}\right]$ and get the trajectory $x(t, \tilde{T}, p)$. Thus, the infinite-dimensional problem (23)-(28) is approximated by finite-dimensional nonlinear programming problem relatively $\tilde{T}, p$ : 


$$
J(\tilde{T}, p)=\int_{t_{1}}^{t_{2}} L(t, x(t, \tilde{T}, p), \tilde{T}, p) d t+\phi\left(x\left(t_{f}, \tilde{T}, p\right), p\right) \rightarrow \inf _{\tilde{T}, p},
$$

with restrictions:

$$
\begin{aligned}
& \tilde{c}=\left[c\left(t_{0}\right)^{T}, \ldots, c\left(t_{N-1}\right)^{T}, \psi^{T}\right]^{T}=0 \\
& \tilde{d}=\left[d\left(t_{0}\right)^{T}, \ldots, d\left(t_{N-1}\right)^{T}, \gamma^{T}\right]^{T} \leq 0
\end{aligned}
$$

and $u(t)$ is approximated.

Software implementation. The above mentioned direct method of numerical solving of optimal control problem is implemented in Java-класів dyn.Opt [18]. In order to use this method in healthinsurance package, a separate process is started in the try-block:

try \{

Process $\mathrm{p}=$ Runtime.getRuntime ()$. \operatorname{exec}($ (java dyn.Opt»);

\}

catch (java.io.IOException ex) \{

System.err.println( «Problems invoking class dyn.Opt:»+ex);

\}

Problem (7) was considered as an example. The problem description was made due to the input text file. So the system variables were by command:

control variable:

state $\mathrm{s} \mathrm{p} \mathrm{s}$

control T

constants:

real kone kminusone $\mathrm{r} \mathrm{W}$

number of time zones:

nodes $=365$

method of nonlinear programming problem solution:

method = dyn_sqp

method of differential equations system integration:

file for output data:

$$
\text { ode }=\text { huen }
$$

accuracy of the method:

$$
\text { output_file }=\text { temperaturecontrol }
$$

$$
\text { epsilon }=1.0 \mathrm{e}-6
$$

The control system (7) with the parameter values is described in the block:

dynamic_equation:

kone $=0.205$

kminusone $=0.01025$

$\mathrm{r}=0.02$

ddt $\mathrm{s}=-\mathrm{kone}{ }^{*} \exp (-\mathrm{r} / \mathrm{T}) * \mathrm{~s} * \mathrm{p}+\mathrm{kminusone}{ }^{*} \exp (-\mathrm{r} / \mathrm{T}) * \mathrm{~s}_{-}$

ddt $\mathrm{p}=-\mathrm{kone}{ }^{*} \exp (-\mathrm{r} / \mathrm{T})^{*} \mathrm{~s}^{*} \mathrm{p}+\mathrm{kminusone}{ }^{*} \exp (-\mathrm{r} / \mathrm{T})^{*} \mathrm{~s}_{-}$

ddt $\mathrm{s}_{-}=$kone $* \exp (-\mathrm{r} / \mathrm{T}) * \mathrm{~s} * \mathrm{p}-\mathrm{kminusone}{ }^{*} \exp (-\mathrm{r} / \mathrm{T}) * \mathrm{~s}_{-}$

Initial conditions block:

initial_condition:

$\mathrm{s}=10000000$ 
$\mathrm{p}=1000$

$\mathrm{s}_{-}=0$

Inequality type restriction:

inequality_constraint:

$\mathrm{d}=-\mathrm{T}+330 \quad \#-\mathrm{T}<=330$

$\mathrm{d}=\mathrm{T}-367 \# \mathrm{~T}<=367$

Quality Criterion Block:

cost_functional:

$\mathrm{W}=0.2$

initial_time $=0.0$

final_time $=30$

$\mathrm{L}=\mathrm{s}_{-}{ }^{*} \mathrm{~s}_{-}-\mathrm{W}^{*} \mathrm{p} * \mathrm{p}$

Data concerning method application are listed below.

The results of nonlinear programming problem solution (23)-(28) are presented in Fig. 3-6.

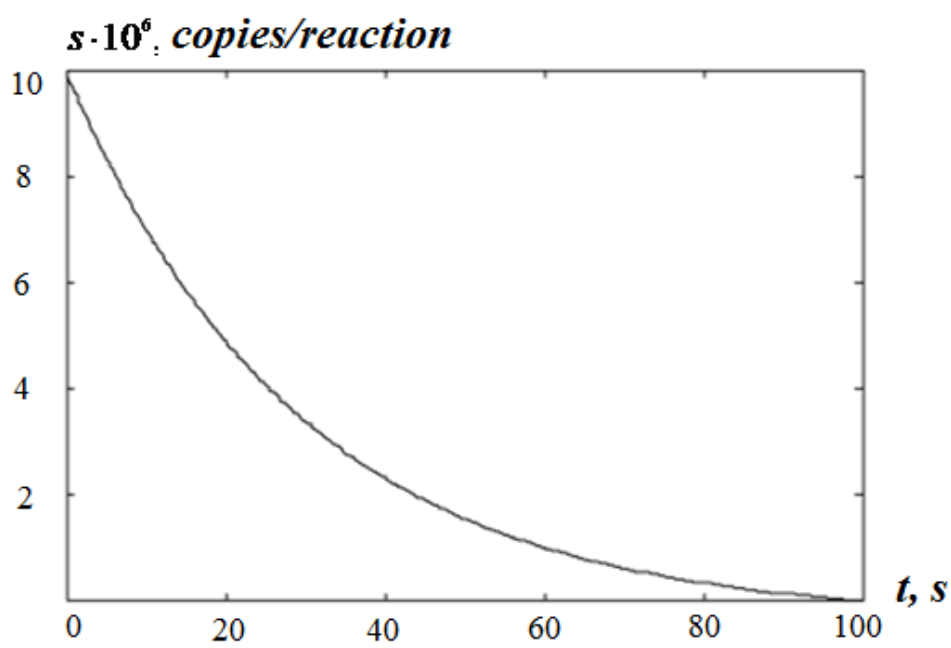

Figure 3. Numerical simulation of the optimal control of PCR annealing stage: change in the amount of single-stranded DNA

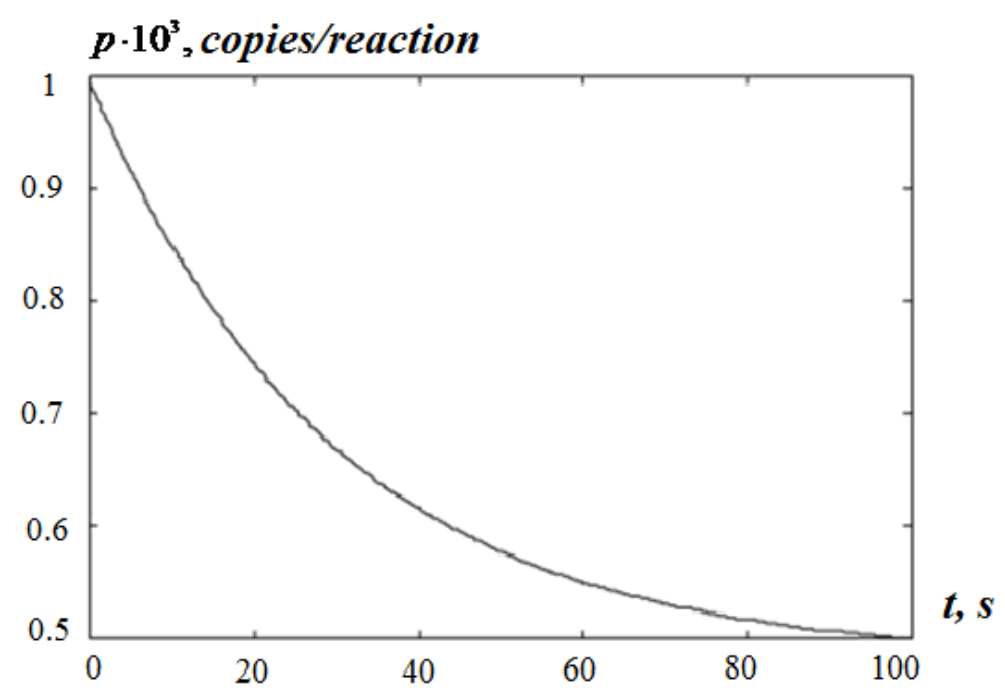

Figure 4. Numerical simulation of the problem of optimal control of PCR annealing stage: change of primer quantity 


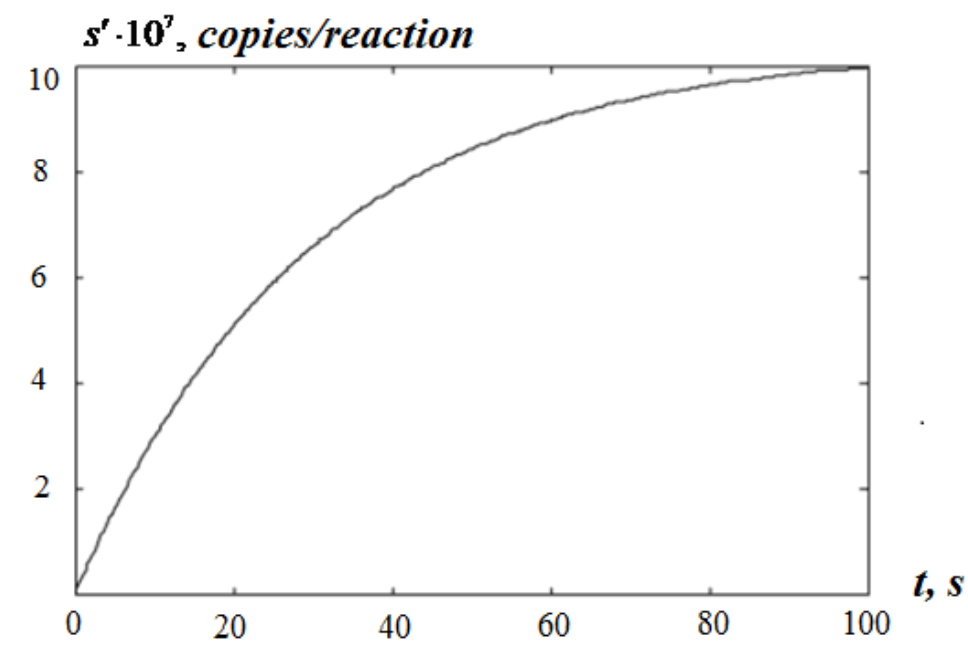

Figure 5. Numerical modeling of optimal control of PCR annealing stage: changes in the amount of singlestranded DNA bound to the primer

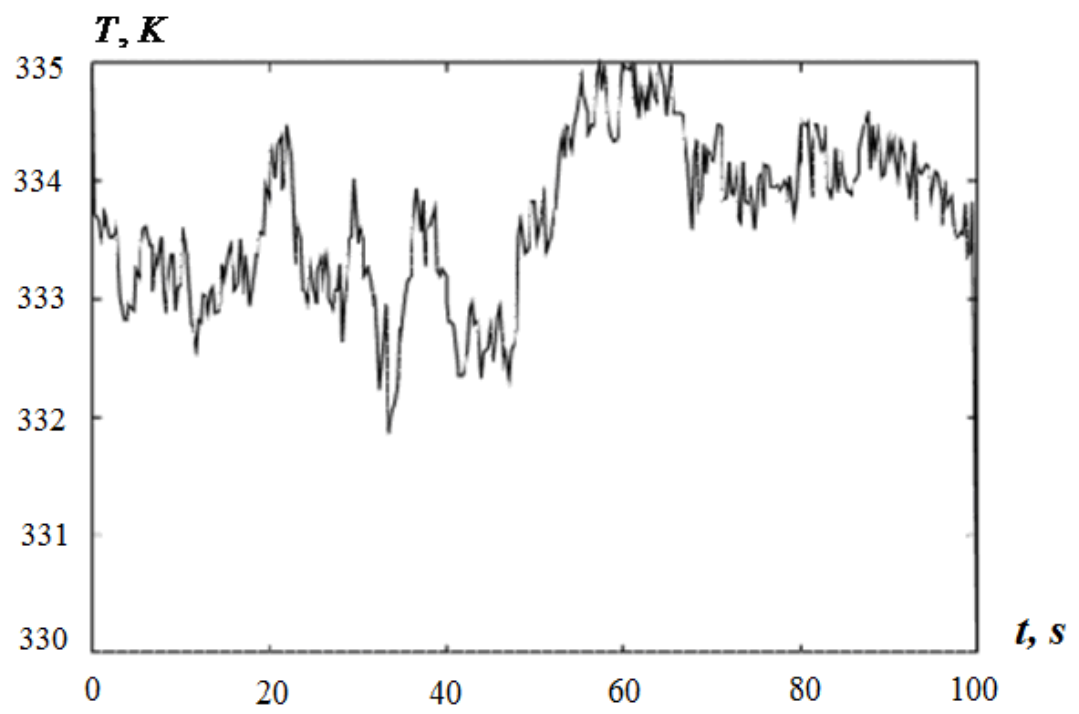

Figure 6. Numerical simulation of the optimal temperature value of PCR annealing stage

Analyzing the results of numerical modeling of problem of the optimal control of PCR annealing stage, it is possible to control the changes in the amount of single chain DNA, primer, and also changes in the number of single-stranded DNA bound during 30 seconds (Figures 3-6).

Using the result of numerical simulation of the problem of optimal control of PCR annealing stage by temperature (Fig. 6), it is possible to obtain as much DNA single-stranded bound to the primer $s^{\prime}$ as possible with the smallest amount of primer $p$ consumtion. The obtained dependence makes it possible to minimize the required time for annealing stage implementation, and can also be used for developing the new test system for PCR.

Conclusions. The problem of optimal control of PCR annealing stage is stated. The Pontryagin maximum principle is applied to the optimal control problem and the required optimality conditions are formulated. The obtained results are the theoretical basis for numerical calculation of the investigated stage optimal control. 
The constructed scheme of temperature setting minimizes the required time for annealing stage implementation, which in general case will ensure the achievement of the minimum time for PCR.

It is necessary to investigate the control of other PCR stages in further researches.

\section{References}

1. Sverstiuk A. S., Bihuniak T. V., Pereviznyk B. O. Ohliad metodiv ta modelei polimerazno-lantsiuhovoi reaktsii. Medychna informatyka ta inzheneriia. № 3. 2014. P. 97-100.

2. Martseniuk V. P., Sverstiuk A. S., Kuchvara O. M. Zadacha optymalnoho keruvannia stadiieiu vidpalu polimerazno-lantsiuhovoi reaktsii. Klynycheskaia ynformatyka y telemedytsyna. № 12. 2015. P. 47-51. https://doi.org/10.31071/kit2015.12.04

3. Aach J., Church G. M. Mathematical models of diffusion-constrained polymerase chainreactions: basis of high-throughput nucleic acid assays and simple self-organizing systems. Journal of Theoretical Biology. 2004. Vol. 228. Pp. 31-46. https://doi.org/10.1016/j.jtbi.2003.12.003

4. Pfaffl M. W. A new mathematical model for relative quantification in real-time RT-PCR. Oxford Journals Science \& Mathematics Nucleic Acids Research. Vol. 29. No. 900. Pp. 45-51. https://doi.org/10.1093/ nar/29.9.e45

5. Xiangchun X., Sinton D., Dongqing L. Thermal end effects on electroosmotic flow in capillary. Int. J. of Heat and Mass transfer. 2004. Vol. 47. Iss. 14-16, pp. 3145-3157. https://doi.org/10.1016/ j.ijheatmasstransfer.2004.02.023

6. Stone E., Goldes J., Garlick M. A multi-stage model for quantitative PCR. Mathematical biosciences and engineering. 2000. Vol. 00. No. 0. Pp. 1-17.

7. Garlick M., Powell J., Eyre D., Robbins T. Mathematically modeling PCR: an asymptotic approximation with potential for optimization Mathematical biosciences and engineering. 2010. Vol. 07. No. 2. Pp. 363-384. https://doi.org/10.3934/mbe.2010.7.363

8. Lukes D. L. Differential Equations: Classical to Controlled. Academic Press. New York. 1982. Vol. 162. $322 \mathrm{p}$.

9. Piccinini L. C., Stampacchia G., Vidossich G. Ordinary Differential Equations in Rn. Problems and Methods Ordinary. Berlin-Heidelberg-New York-Tokyo. Springer-Verlag. 1984. Vol. XII. 385 p. https://doi.org/10.1007/978-1-4612-5188-0

10. Macki J., Strauss A. Introduction to Optimal Control Theory. Springer-Verlag. New York. 1982. Vol. XIV. 168 p. https://doi.org/10.1007/978-1-4612-5671-7

11. Fleming W. H., Rishel R. W. Deterministic and Stochastic Optimal Control. Springer Verlag. New York. 1975. Vol. XIII. 222 p. https://doi.org/10.1007/978-1-4612-6380-7

12. Kamien M. I., Schwartz N. L. Dynamic Optimization. North-Holland. Amsterdam. 1991. Vol. 3. 272 p.

13. Pontriahyn L. S., Boltianskyi V. H., Hamkrelydze R. V., Myshchenko E. F. Matematycheskaia teoryia optymalnykh protsessov. M.: 1983. $393 \mathrm{c}$.

14. Kelly K., Kostin M. Non-Arrhenius rate constants involving diffusion and reaction. Journal of Chemical Physics. 1986. Vol. 85. Iss. 12. Pp. 7318-7335. https://doi.org/10.1063/1.451371

15. John T. Betts. Practical Methods for Optimal Control Using Nonlinear Programming Society for Industrial and Applied Mathematics. 2001. 190 p.

16. O. von Stryk, R. Bulirsch. Direct and indirect methods for trajectory optimization. Annals of Operations Research. 1992. No. 2. Vol. 37. Iss. 1-4. Pp. 357-373. https://doi.org/10.1007/BF02071065

17. Arthur E. Bryson, Jr. and Yu-Chi Ho. Applied optimal control. Hal-sted Press, New York, 1975. 481 p.

18. B. C. Fabien Some tools for the direct solution of optimal control problems. Advances in Engineering Software. 1998. Vol. 29. Pp. 45-61. https://doi.org/10.1016/S0965-9978(97)00025-2

\section{Список використаної літератури}

1. Сверстюк А. С., Бігуняк Т. В., Перевізник Б. О. Огляд методів та моделей полімеразно-ланцюгової реакції. Медична інформатика та інженерія. № 3. 2014. С. 97-100.

2. Марценюк В. П., Сверстюк А. С., Кучвара О. М. Задача оптимального керування стадією відпалу полімеразно-ланцюгової реакції. Клиническая информатика и телемедицина. № 12. 2015. С. 47-51. https://doi.org/10.31071/kit2015.12.04.

3. Aach J., Church G. M. Mathematical models of diffusion-constrained polymerase chainreactions: basis of high-throughput nucleic acid assays and simple self-organizing systems. Journal of Theoretical Biology. 2004. Vol. 228. Pp. 31-46. https://doi.org/10.1016/j.jtbi.2003.12.003

4. Pfaffl M. W. A new mathematical model for relative quantification in real-time RT-PCR. Oxford Journals Science \& Mathematics Nucleic Acids Research. Vol. 29. No. 900. Pp. 45-51. https://doi.org/10.1093/ nar/29.9.e45

5. Xiangchun X., Sinton D., Dongqing L. Thermal end effects on electroosmotic flow in capillary. Int. J. of Heat and Mass transfer. 2004. Vol. 47. Iss. 14-16. Pp. 3145-3157. https://doi.org/10.1016/ j.ijheatmasstransfer.2004.02.023 
6. Stone E., Goldes J., Garlick M. A multi-stage model for quantitative PCR. Mathematical biosciences and engineering. 2000. Vol. 00. No. 0. Pp. 1-17.

7. Garlick M., Powell J., Eyre D., Robbins T. Mathematically modeling PCR: an asymptotic approximation with potential for optimization Mathematical biosciences and engineering. 2010. Vol. 07. No. 2. Pp. 363-384. https://doi.org/10.3934/mbe.2010.7.363

8. Lukes D. L. Differential Equations: Classical to Controlled. Academic Press. New York. 1982. Vol. 162. $322 \mathrm{p}$.

9. Piccinini L. C., Stampacchia G., Vidossich G. Ordinary Differential Equations in Rn. Problems and Methods Ordinary. Berlin-Heidelberg-New York-Tokyo. Springer-Verlag. 1984. Vol. XII. 385 p. https://doi.org/10.1007/978-1-4612-5188-0

10. Macki J., Strauss A. Introduction to Optimal Control Theory. Springer-Verlag. New York. 1982. Vol. XIV. 168 p. https://doi.org/10.1007/978-1-4612-5671-7

11. Fleming W. H., Rishel R. W. Deterministic and Stochastic Optimal Control. Springer Verlag. New York. 1975. Vol. XIII. 222 p. https://doi.org/10.1007/978-1-4612-6380-7

12. Kamien M. I., Schwartz N. L. Dynamic Optimization. North-Holland. Amsterdam. 1991. Vol. 3. 272 p.

13. Понтрягин Л. С., Болтянский В. Г., Гамкрелидзе Р. В., Мищенко Е. Ф. Математическая теория оптимальных процессов. М.: 1983. 393 с.

14. Kelly K., Kostin M. Non-Arrhenius rate constants involving diffusion and reaction. Journal of Chemical Physics. 1986. Vol. 85. Iss. 12. Pp. 7318-7335. https://doi.org/10.1063/1.451371

15. John T. Betts. Practical Methods for Optimal Control Using Nonlinear Programming Society for Industrial and Applied Mathematics. 2001. 190 p.

16. O. von Stryk, R. Bulirsch. Direct and indirect methods for trajectory optimization. Annals of Operations Research. 1992. No. 2. Vol. 37. Iss. 1-4. Pp. 357-373. https://doi.org/10.1007/BF02071065

17. Arthur E. Bryson, Jr. and Yu-Chi Ho. Applied optimal control. Hal-sted Press, New York, 1975. 481 p.

18. B. C. Fabien Some tools for the direct solution of optimal control problems. Advances in Engineering Software. 1998. Vol. 29. Pp. 45-61. https://doi.org/10.1016/S0965-9978(97)00025-2

\title{
УДК 510.87:544.431.7:577.21
}

\section{ЧИСЕЛЬНИЙ АЛГОРИТМ ПОБУДОВИ ОПТИМАЛЬНОГО КЕРУВАННЯ СТАДІЕЮ ВІДПАЛУ ПОЛІМЕРАЗНО-ЛАНЦЮГОВОЇ РЕАКЦІї}

\section{Андрій Сверстюк}

\author{
Тернопільський державний медичний університет ім. I. Я. Горбачевського, \\ Тернопіль, Україна
}

\begin{abstract}
Резюме. Застосовано загальну методологію керування для отримання розв'язку задачі оптимального перебігу стадї відпалу в полімеразно-ланцюговій реакції з метою ефективного проведення досліджуваної та можливістю забезпечення багатостадійного ииклічного режиму зміни температури. Досліджувана стадія відпалу повинна відбуватися при певних температурах та протягом відповідного часу, оскільки в іншому випадку необхідних перетворень молекул ДНК може не відбутися. Використано розроблену модель стадії відпалу полімеразно-ланцюгової реакиї̈, яка враховує співвідномення кількості одноланцюгових ДНК, праймеру, одноланцюгових ДНК зв'язаних з праймером, прямої та зворотної швидкості реакиії для відпалу. У досліджуваній моделі використано рівняння Арреніуса, яке враховує залежність швидкості реакиії від абсолютної температури. Застосовано принции максимуму Понтрягіна до задачі оптимального керування стадї відпалу та сформульовано необхідну умову оптимальності. Розроблено прямий метод чисельного розв'язування задачі оптимального керування стадії відпалу, який реалізовано в пакеті Јаvа-класів. У вигляді графіків представлені результати чисельного моделювання задачі оптимального керування стадї відпалу полімеразно-ланцюгової реакції для зміни кількості одноланџюгових ДНК, кількості праймеру, зміни кількості одноланиюгових ДНК, які з'єднані з праймером, та оптимального значення температури досліджуваної стадії. Отримані результати чисельного моделювання задачі оптимального керування стадії відпалу полімеразноланцюгової реакиії допоможуть мінімізувати необхіднии час реалізаџії даної стадії. Побудована таким чином схема задавання температури мінімізує необхідний час реалізації стадії відпалу, щзо в загальному випадку забезпечить досягнення мінімального часу проведення полімеразно-ланцюгової реакції.
\end{abstract}

Ключові слова: полімеразна ланцюгова реакиія, стадія відпалу, оптимальне керування, принщип максимуму Понтрягіна. 